OPEN ACCESS

Edited by:

Jochen Mattner,

University of Erlangen Nuremberg,

Germany

Reviewed by:

Mitja Kosnik,

University Clinic of Pulmonary and

Allergic Diseases Golnik, Slovenia

Cristoforo Incorvaia Incorvaia, Gaetano Pini Specialist Orthopedic

Trauma Center, Italy

Arzu Didem Yalcin,

Academia Sinica, Taiwan

*Correspondence:

Julia Eckl-Dorna

Julia.eckl-dorna@meduniwien.ac.at

tORCID:

Mohammed Zghaebi orcid.org/0000-0002-7636-2601

Maria Byazrova

orcid.org/0000-0002-9858-7596

Sabine Flicker

orcid.org/0000-0003-4768-8693

Sergio Villazala-Merino orcid.org/0000-0002-6791-3272

Nicholas J. Campion

orcid.org/0000-0003-3345-9486

Victoria Stanek

orcid.org/0000-0003-3445-0934

Heimo Breiteneder

orcid.org/0000-0003-2022-8689

Alexander Filatov

orcid.org/0000-0002-6460-9427

Musa Khaitov

orcid.org/0000-0003-4961-9640

Verena Niederberger-Leppin

orcid.org/0000-0002-2918-2608

Julia Eckl-Dorna

orcid.org/0000-0001-5981-1607

Rudolf Valenta

orcid.org/0000-0001-5944-3365

Specialty section:

This article was submitted to Vaccines and Molecular Therapeutics, a section of the journal

Frontiers in Immunology

Received: 27 October 2021 Accepted: 08 November 2021 Published: 20 December 2021

\section{Tracing Human IgE B Cell Antigen Receptor-Bearing Cells With a Monoclonal Anti-Human IgE Antibody That Specifically Recognizes Non-Receptor-Bound IgE}

\author{
Mohammed Zghaebi ${ }^{1 \dagger}$, Maria Byazrova ${ }^{2,3 \dagger}$, Sabine Flicker $^{4 \dagger}$, Sergio Villazala-Merino ${ }^{1 \dagger}$, \\ Nicholas J. Campion ${ }^{1+}$, Victoria Stanek ${ }^{1 \dagger}$, Aldine Tu ${ }^{1}$, Heimo Breiteneder ${ }^{5 t}$, \\ Alexander Filatov ${ }^{2,3+}$, Musa Khaitov ${ }^{2,6 t}$, Verena Niederberger-Leppin ${ }^{1 t}$, \\ Julia Eckl-Dorna ${ }^{1 * t}$ and Rudolf Valenta ${ }^{2,4,7,8 t}$

\begin{abstract}
${ }^{1}$ Department of Otorhinolaryngology, Medical University of Vienna, Vienna, Austria, ${ }^{2}$ National Research Centre (NRC) Institute of Immunology, Federal Medical-Biological Agency (FMBA) of Russia, Moscow, Russia, ${ }^{3}$ Department of Immunology, Faculty of Biology, Lomonosov Moscow State University, Moscow, Russia, ${ }^{4}$ Division of Immunopathology, Department of Pathophysiology and Allergy Research, Center for Pathophysiology, Infectiology and Immunology, Medical University of Vienna, Vienna, Austria,

${ }^{5}$ Division of Medical Biotechnology, Department of Pathophysiology and Allergy Research, Center for Pathophysiology, Infectiology and Immunology, Medical University of Vienna, Vienna, Austria, 6 Immunology Department, Pirogov Russian National Research Medical University, Moscow, Russia, ${ }^{7}$ Department of Clinical Immunology and Allergy, Sechenov First
\end{abstract} \\ Moscow State Medical University, Moscow, Russia, ${ }^{8}$ Karl Landsteiner University of Health Sciences, Krems, Austria
}

Up to $30 \%$ of the population suffers from immunoglobulin E (lgE)-mediated allergies. Despite current stepwise gating approaches, the unambiguous identification of human lgE-producing cells by flow cytometry and immunohistology remains challenging. This is mainly due to the scarcity of these cells and the fact that lgE is not only expressed in a membrane-bound form on the surface of IgE-producing cells in form of the B cell antigen receptor (BCR), but is more frequently found on various cell types bound to the low and high affinity receptors, CD23 and $\mathrm{F}_{\mathrm{C} \in \mathrm{RI}}$, respectively. Here we sought to develop a sequential gating strategy for unambiguous detection of cells bearing the $\lg \mathrm{E} B \mathrm{R}$ on their surface. To that aim we first tested the monoclonal anti-lgE antibody omalizumab for its ability to discriminate between IgE BCR and receptor-bound IgE using cells producing IgE or bearing IgE bound to CD23 as well as basophils exhibiting FC€RI receptor-bound IgE. Using flow cytometry, we demonstrated that omalizumab recognized IgE producing cells with a high sensitivity of up to $1 \mathrm{lgE}^{+}$cell in 1000 human peripheral blood mononuclear cells (PBMCs). These results were confirmed by confocal microscopy both in cell suspensions as well as in nasal polyp tissue sections. Finally, we established a consecutive gating strategy allowing the clear identification of class-switched, allergenspecific lgE ${ }^{+}$memory B cells and plasmablasts/plasma cells in human PBMCs. Birch pollen specific $\mathrm{gE}^{+}$memory $\mathrm{B}$ cells represented on average $0.734 \%$ of total $\mathrm{CD} 19^{+} \mathrm{B}$ cells in allergic patients after allergen exposure. Thus, we developed a new protocol for exclusive staining of non-receptor bound allergen-specific $\operatorname{lgE}^{+} \mathrm{B}$ cell subsets in human samples.

Keywords: omalizumab, IgE, B cells, allergy, CD23, spiking, PBMCs, FceRI 


\section{INTRODUCTION}

Allergy, a worldwide disease affecting up to $30 \%$ of the world population, is characterized by immunoglobulin $\mathrm{E}$ ( IgE) production specific to the culprit allergens (1). Though IgE is continuously produced and returns to baseline levels within few days after removal by extracorporeal immunoadsorption in sensitized patients (2), the location and the extent of contribution of $\operatorname{IgE} \mathrm{B}$ cell antigen receptor (BCR) bearing memory B cells (MBCs) to human IgE production is not fully clarified $(3,4)$. This is mainly due to limited knowledge of these cells (5) as the characterization of human IgE-producing cells in blood by flow cytometry is challenging due to several reasons: Firstly, IgE BCR bearing cells are extremely rare in the blood. They are estimated to represent between 0.0019 and $0.3 \%$ of total B cells in allergic subjects (6-9) and to contribute to $0.2 \%$ of the human serum $\operatorname{IgE}(4,10)$. Secondly, the $\operatorname{IgE}$ BCR is expressed at much lower levels than BCRs composed of other immunoglobulins such as IgG or IgM (7). This might be due to the suboptimal polyadenylation signals in the $\operatorname{IgE}$ transcripts (11), which makes the clear distinction of these cells from background staining more difficult. Thirdly and most importantly, IgE occurs in two different forms on the surface of immune cells: in the form of an $\operatorname{IgE} \operatorname{BCR}(12,13)$ or bound to its high or low affinity receptors, FceRI and CD23 respectively. In addition, other IgE binding factors have been described such as epsilon-binding protein (14). FceRI is mainly present on the surface of basophils, mast cells and dendritic cells, while CD23 is predominantly expressed by $\mathrm{B}$ cells and monocytes $(15,16)$. Thus, especially CD23-bound IgE renders the detection of $\operatorname{IgE}^{+}$ BCR bearing cells difficult as many commonly used anti-human IgE antibodies are unable to discriminate between the membrane-expressed and receptor-bound form of IgE.

To exclude B cells bearing IgE bound to CD23 from the analysis of $\operatorname{IgE}^{+} \mathrm{B}$ cells, various approaches have been tried. Early strategies included stripping IgE from CD23 by lactic acid wash $(17,18)$. However, this treatment may be damaging for the cells especially if they are planned to be used further on e.g. for functional assays after flow cytometric sorting (19). The compromise of excluding cells double positive for IgE and CD23 in the flow cytometer comprises the danger of accidentally removing true $\operatorname{IgE}^{+} \mathrm{B}$ cells having both free as well as CD23-bound IgE (20). Thus, more recent approaches to circumvent this issue applied stepwise gating for $\operatorname{IgE}^{+}$memory $\mathrm{B}$ cells and plasmablasts (PBs)/plasma cells (PCs) firstly using antiCD19 and anti-CD38, followed by sequential exclusion of $\operatorname{IgM}^{+}$, $\operatorname{IgD}^{+}, \operatorname{IgA}^{+}$and $\operatorname{IgG}^{+}$cells $(6,7,21)$ or intracellular staining for $\operatorname{IgE}$ for identification of IgE-producing cells $(5,8)$. Nevertheless, these strategies identify $\mathrm{IgE}^{+}$cells only indirectly by stepwise exclusion of other cells and may also miss $\operatorname{IgE}^{+} \mathrm{B}$ cells having IgG bound to their Fc $\gamma$ RIIb receptor (22-24). Therefore, a flow cytometric approach allowing for the direct and clear identification of $\operatorname{IgE}^{+}$BCR bearing and IgE-producing B cells in human samples is needed.

Several anti-IgE antibodies have been developed for the treatment of severe forms of allergy (20). Among these, omalizumab is the only one licensed for treatment. It reduces the levels of free IgE in the blood by $99 \%$ within a few hours after administration (25) and is successfully used to treat severe asthma and urticaria $(26,27)$. It is known to bind to the Ce3 region of IgE where the contact sites for both CD23 and FceRI are situated. As a result, omalizumab is thought to bind to $\operatorname{IgE}$ only in its free and not in its receptor-bound form and is thus a candidate for exclusively detecting $\operatorname{IgE}^{+} \mathrm{BCR}$ bearing $\mathrm{MBC}$ or $\operatorname{IgE}^{+}$PBs/PCs (28).

In this study we investigated the suitability of fluorescently labelled omalizumab for the staining of non-receptor bound $\operatorname{IgE}^{+}$ B cells by flow cytometry. Furthermore, we aimed to establish a consecutive gating strategy for the clear identification of allergenspecific $\mathrm{IgE}^{+}$BCR bearing $\mathrm{MBC}$ and $\mathrm{PBs} / \mathrm{PCs}$ based on double staining with omalizumab and allergen.

\section{MATERIAL AND METHODS}

\section{Cell Lines}

A human Epstein Barr virus-transformed B-cell line (EBV B cells) expressing CD23 (15) and the human IgE myeloma cell line (U266) (29) were cultured in Roswell Park Memorial Institute (RPMI) 1640 Glutamax medium (ThermoFisher Scientific, Waltham, Massachusetts) supplemented with $10 \%$ fetal bovine serum (ThermoFisher Scientific) and 1\% penicillin/ streptomycin (ThermoFisher Scientific) at $37^{\circ} \mathrm{C}$ and $5 \% \mathrm{CO}_{2}$. Cell counting was performed in the presence of Trypan blue to ensure a cell viability of more than $80 \%$. CD23 expression on the surface of EBV B cells was confirmed by flow cytometry (see Supplementary Table S1).

\section{Protein Expression (Bet v 1) and Purification}

A codon-optimized synthetic gene encoding Bet v 1.0101 was inserted into the pET28b $(+)$ expression vector (Novagen, Darmstadt, Germany) and expressed in Escherichia coli BL21 [DE3] cells (New England Biolabs, MA, USA). Expression was carried out in standard E. coli culture media at $30^{\circ} \mathrm{C}$. Protein expression was induced with $1 \mathrm{mM}$ isopropyl $\beta$-D-1thiogalactopyranoside at an OD600 nm of 0.8. After overnight expression, cells were harvested, cell pellets were frozen for 24 hours, and then lysed by freeze-thawing 3 times in $50 \mathrm{mM}$ sodium phosphate buffer, $\mathrm{pH}$ 6.0, supplemented with protease inhibitor tablets (Roche Diagnostics, Basel, Switzerland) and 10 $\mathrm{mM}$ dithiothreitol. Purification was achieved via hydrophobic interaction chromatography (Phenyl Sepharose 6 Fast Flow, GE Healthcare, Uppsala, Sweden), ion exchange chromatography (Q Sepharose Fast Flow, GE Healthcare) and gel chromatography filtration on a Sephacryl S-200 HR column (GE Healthcare). The purified Bet v 1 protein was dialyzed against $10 \mathrm{mM}$ sodium phosphate buffer, pH 7.5. Endotoxin Removal Beads (Miltenyi Biotec, Gladenbach, Germany) were used to remove lipopolysaccharides. The protein was stored at $-80^{\circ} \mathrm{C}$ until use.

\section{Peripheral Blood Mononuclear Cells (PBMCs) Preparation and Basophil Isolation}

Heparinized blood was obtained from birch pollen allergic patients $(n=5)$ and non-allergic subjects $(n=3)$ after obtaining a 
written informed consent. Blood drawing was performed with the approval of the Ethics Committee of the Medical University of Vienna (EK508/2011). Where indicated, patients had been provoked with birch pollen extract on three consecutive days starting one week prior to the blood draw (EK1320/2021).

PBMCS were isolated from heparinized human blood using Ficoll density gradient centrifugation (GE Healthcare). Enrichment of basophils was performed using the MACS Basophil Isolation Kit II (Miltenyi Biotech) according to the manufacturer's protocol and as previously described (30). The purity of the isolated basophils was confirmed by staining for CD123 and FceRI by flow cytometry (see Supplementary Table S1).

\section{Flow Cytometry}

The anti-human IgE antibody omalizumab (=Xolair ${ }^{\circledR}$, Novartis, Basel, Switzerland) as well as human IgG1, $\kappa$ (Sigmaaldrich, St. Louis, Missouri) were labelled with Alexa Fluor 647 Conjugation Kit-Lightning-Link (Abcam, Cambridge, MA) and Bet v 1 was labelled with PE/R-Phycoerythrin Conjugation Kit LightningLink (Abcam) according to the manufacturer's instructions. For the surface staining of PBMCs, basophils, and EBV B cells, cells were incubated for 20 minutes on ice in blocking buffer of $1 \%$ bovine serum albumin (BSA), 5\% goat serum, 5\% mouse serum in PBS (Morphisto, Frankfurt am Main, Germany). Thereafter, EBV B cells were incubated for another 20 minutes in the aforementioned blocking buffer on ice with humanized chimeric monoclonal IgE specific for the major birch pollen allergen Bet v 1 (31) at a final concentration of $6 \mu \mathrm{g} / \mathrm{ml}$. After washing, cells were stained with respective antibodies (see Supplementary Table S1) and fixable viability dye e780 (ThermoFisher Scientific) for 20 minutes on ice in PBS containing 1\% BSA (Sigmaaldrich). Bet v 1-PE staining was only performed for PBMCs. Cells were then washed 3 times and resuspended in blocking buffer.

For intracellular staining of U266 cells, cells were stained with fixable viability dye e780 (ThermoFisher Scientific) prior to fixation with formalin $4 \%$ (Morphisto) at $37^{\circ} \mathrm{C}$ for 10 minutes. Cells were then washed and incubated with a permeabilization buffer (PBS, 1\% BSA, 0.1\% Saponin) containing 5\% goat serum and 5\% mouse serum for 20 minutes. After washing, cells were stained with respective antibodies (see Supplementary Table S1) in permeabilization buffer. After staining, cells were rinsed again 3 times with 1\% BSA in PBS and resuspended in the same buffer for acquisition in the flow cytometer. For PBMC spiking experiments, U266 cells at indicated numbers were mixed with indicated numbers of PBMCs prior to fixation and intracellular staining as described above for U266 cells.

Compensation beads (ThermoFisher Scientific) were used to optimize acquisition settings. Furthermore, quality control measures to sustain the instrument's optics, fluidics, and electronics according to the manufacturer's instructions were performed regularly by using CS\&T beads (BD bioscience, Franklin Lakes, New Jersey, USA). Flowjo software version 10.7.2 (Tree Star Inc., Ashland, Oregon, USA) was used to analyze data obtained on a BD LSRFortessa (BD Biosciences). At least 100,000 alive cells were acquired per sample.

\section{Cell and Tissue Preparation for Confocal Analysis}

Single cell suspensions of EBV-transformed B cells, U266 cells and enriched basophils were prepared onto slides using Shandon Cytospin 3 (ThermoFisher Scientific). A nasal polyp sample (EK1956/2018) embedded in OCT medium and stored at $-80^{\circ} \mathrm{C}$ was cut in $5 \mu \mathrm{m}$ cryosections. Subsequently U266 cells were spiked onto the tissue slide using the cytospin. Thereafter tissue was fixed using 4\% formalin (Morphisto) and respective antibodies (see Supplementary Table S2) were applied to the cryosections overnight in PBS (Morphisto) containing 0.1\% Saponin (Sigmaaldrich) and 2\% of bovine serum albumin (BSA). Slides were washed and stained with the secondary antibody for CD19 for 1 hour at room temperature. Slides were counterstained with DAPI (ThermoFisher Scientific) to reveal nuclei and mounted with ProLong Gold Antifade Mountant (ThermoFisher Scientific). Images of slides were acquired using a confocal laser scanning microscope (Nikon, Tokyo, Japan, 60x magnification).

\section{Statistical Analysis}

For the FACs staining of U266 cells, EBV B cells, and basophils, Flowjo-generated frequencies and gated event counts were exported to Excel (Microsoft, Redmond, WA) to calculate the mean and standard deviation for three independent experiments. For the linearity assessment for the spiking of PBMCs with U266, values were calculated as follows:

Percentage of U266 Observed $=$ measured percentage omalizumab - mean measured percentage isotype

GraphPad Prism software version 9 (GraphPad Software, La Jolla, CA) was used to calculate Pearson correlation coefficient. A $p$ value less than 0.05 was considered statistically significant.

For the quantification of IgE-bearing B cells in the blood of allergen-provoked patients, the percentage of $\operatorname{IgE}^{+}$Bet $\mathrm{v} 1^{+}$ MBCs of total B cells was calculated as the percentage of alive $\mathrm{CD}_{19}{ }^{+} \mathrm{CD} 8^{\mathrm{dim} /-} \mathrm{IgD}^{-} \mathrm{IgM}^{-} \mathrm{IgE}^{+}$Bet v $1^{+}$cells of total CD19 cells, and the percentage of $\operatorname{IgE}^{+}$Bet $\mathrm{v} 1^{+} \mathrm{PBs} / \mathrm{PCs}$ of total B cells was calculated as the percentage of alive $\mathrm{CD}_{1} 9^{+} \mathrm{CD}_{3} 8^{+} \mathrm{IgD}$ $\mathrm{IgM}^{-} \mathrm{IgE}^{+}$Bet $\mathrm{v} 1^{+}$cells of total $\mathrm{CD} 19^{+}$cells. The same strategy was applied for the non-allergic individuals.

\section{RESULTS}

\section{Omalizumab Exclusively Detects-IgE Producing Cells but Not Receptor-Bound IgE in Cellular Flow Cytometric and Confocal Assays}

In order to test if the humanized monoclonal anti-human IgE antibody omalizumab fulfilled the requirements of reliably detecting IgE as present in the IgE BCR but not receptorbound IgE we performed fluorescent staining in three different cell types: (i) In the human IgE myeloma cell line U266, an IgEproducing cell line that has previously been used as a surrogate for BCR-bearing and IgE-producing cells $(32,33)$ (ii) In an Epstein barr virus (EBV)-transformed B cell line (EBV B cells) expressing high levels of CD23 incubated with humanized birch 
pollen specific IgE prior to staining $(15,34)$ and (iii) in human basophils enriched from blood of donors and thus bearing IgE bound to their high affinity receptor FceRI. IgE was detected either with omalizumab labelled with AF647, the appropriate isotype control (human IgG1א labelled with AF647) or a commercially available polyclonal anti-IgE FITC antibody (see Supplementary Table S1). Omalizumab-AF647 detected IgE only in U266 cells but was unable to stain IgE if bound to CD23 (EBV cells) or FceRI (Basophils) (omalizumab AF-647 positive cells: U266 cells: $96.02 \pm 1.89 \%$, EBV cells: $0.20 \pm 0.11 \%$, Basophils: $0.41 \pm 0.68 \%)$. Representative plots of three independent experiments performed in duplicates are shown in Figure 1A. No positive staining was observed using the respective isotype control for any of the conditions tested (IgG1א AF-647 positive cells: U266 cells: $0.71 \pm 0.91 \%$, EBV cells: $0.11 \pm 0.06 \%$, Basophils: $0.38 \pm 0.42 \%$ ) (Figure 1B). IgEpositive cells were observed in all three cell types when polyclonal anti-IgE was used (IgE-FITC positive cells: U266 cells: $96.7 \pm$ $1.24 \%$, EBV cells: $42.87 \pm 6.30$, Basophils: $91.48 \pm$ 11.24\%) (Figure 1C).

We further aimed to corroborate our results using confocal microscopy. Cells producing IgE, cells bearing IgE bound to CD23 and basophils as described above were transferred onto slides using a cytospin followed by staining with omalizumabAF647, the respective isotype control (human IgG1א-AF647) or polyclonal anti-human IgE FITC. Only IgE-producing cells were positive for omalizumab-AF647 but not the respective isotype control (Figure 2A and Supplementary Figure S1). No positive staining for omalizumab-AF647 was detected in cells bearing IgE bound to the CD23 receptor or FceRI. By contrast, polyclonal anti-human IgE stained IgE both in IgE-producing cells and cells bearing $\mathrm{IgE}$ in a receptor-bound form in all three cell types as shown in Figure 2B.

\section{Omalizumab Detects IgE-Producing Cells in Human Nasal Polyp Tissue}

Having established that omalizumab was able to detect cells bearing non-receptor-bound IgE in cell suspensions, we next assessed if it would detect these cells also in a tissue-based context using a nasal polyp biopsy. To that aim, we spiked IgE-producing cells (U266 cell line) onto polyp tissue sections prior to staining with omalizumab-AF647. Tissue samples were co-stained with anti-human CD19 to detect tissue-resident B cells and DAPI to stain for nuclei (Supplementary Table S2). We observed positive staining of IgE-bearing cells in human polyp tissue with omalizumab AF647 (Figure 3) while human IgG1k AF647 did not show any positive staining (Supplementary Figure S2).

\section{IgE-Producing Cells Present in PBMCs Are Revealed With a High Sensitivity by Omalizumab-Based Flow Cytometric Assays}

To determine the sensitivity of omalizumab in detecting IgE BCR bearing cells within human PBMCs, we spiked the IgEproducing U266 cell line at different ratios into PBMCs of non-allergic patients. The ratio of U266:PBMCs ranged from $1: 10(10 \%)$ to $1: 1000(0.1 \%)$ prior to staining with omalizumabAF647. Omalizumab-AF647-positive cells were observed in all three spiking conditions tested (10\% spiking: $7.31 \pm 1.18 \%, 1 \%$ spiking: $0.92 \pm 0.18 \%, 0.1 \%$ spiking: $0.09 \pm 0.03 \%)$. Representative plots from three independent experiments performed in duplicates are shown in Figure 4A. The measured percentage of IgE-producing cells in PBMCs by flow cytometry showed a strong and significant correlation with the expected percentage (Pearsons's correlation coefficient $r=0.99$, $\mathrm{p}=0.015$ ) (Figure $4 \mathbf{B}$ ) and was highly reproducible (range of standard deviation: $0.03-1.18 \%)$.

\section{Detection of IgE BCR-Bearing B Cells Specific for the Major Birch Pollen Allergen Bet v 1 in Blood of Birch Pollen Allergic Patients by Omalizumab}

As proof of concept, we aimed to identify blood-derived allergenspecific MBCs and/or PBs/PCs bearing a surface IgE BCR in birch pollen allergic patients by employing a sequential gating strategy based on recent publications $(6,7,9)$. To that aim, PBMCs were isolated from birch pollen allergic donors one week after controlled nasal allergen challenge as well as from nonallergic donors. They were stained with fixable viability dye e780, anti-CD19 PerCP-Cy5.5, anti-CD38 BV510, anti-IgM BV421, anti-IgD BV605, Bet $\mathrm{v} 1$ labelled with PE (Bet $\mathrm{v} 1$ 1-PE) and omalizumab-AF647. Gating was performed using corresponding isotype controls. After selecting for alive cells, we separated PBs/ PCs from naïve and memory B cells based on their staining for CD19 and CD38 (Figure 5A). Subsequently we identified classswitched $\mathrm{B}$ cells by negative staining for IgM and $\mathrm{IgD}$ in both populations. In class-switched cells of the respective populations, we finally gated on cells double positive for the allergen Bet v 1PE and omalizumab-AF647. Using this gating strategy, the percentage of Bet $\mathrm{v}^{+} \mathrm{IgE}^{+} \mathrm{MBCs}$ in the blood of allergenexposed allergic patients ranged from $2.14 \%$ to $4.17 \%$ (mean $=3.228 \pm 0.721 \%, \mathrm{n}=5)$ whereas they absent in nonallergic donors (mean $=0.041 \pm 0.003 \%, \mathrm{n}=3$ ) (Figure 5B) (Supplementary Table S3). We were also able to detect a small population of $\mathrm{IgE}^{+} \mathrm{PBs} / \mathrm{PCs}$ in 3 out of 5 allergic patients, the percentage of these cells ranged between $0 \%$ to $7.14 \%$ (mean $=2.030 \pm 2.655 \%, n=5)$ in the blood of birch pollen allergic patients one week after allergen contact and were completely absent in the case of non-allergic patients (Figure 5C and Supplementary Table S3).

\section{DISCUSSION}

Here we have shown that the anti-human IgE antibody omalizumab recognizes IgE B cell antigen receptor whilst omitting cells bearing IgE bound to CD23 or FceRI both in cellular suspension as well as in tissue using flow cytometry and confocal microscopy. Spiking experiments revealed that omalizumab was able to detect IgE-bearing cells over a wide range up to a ratio of $1 \mathrm{IgE}$-producing cells in 1000 PBMCs thus 

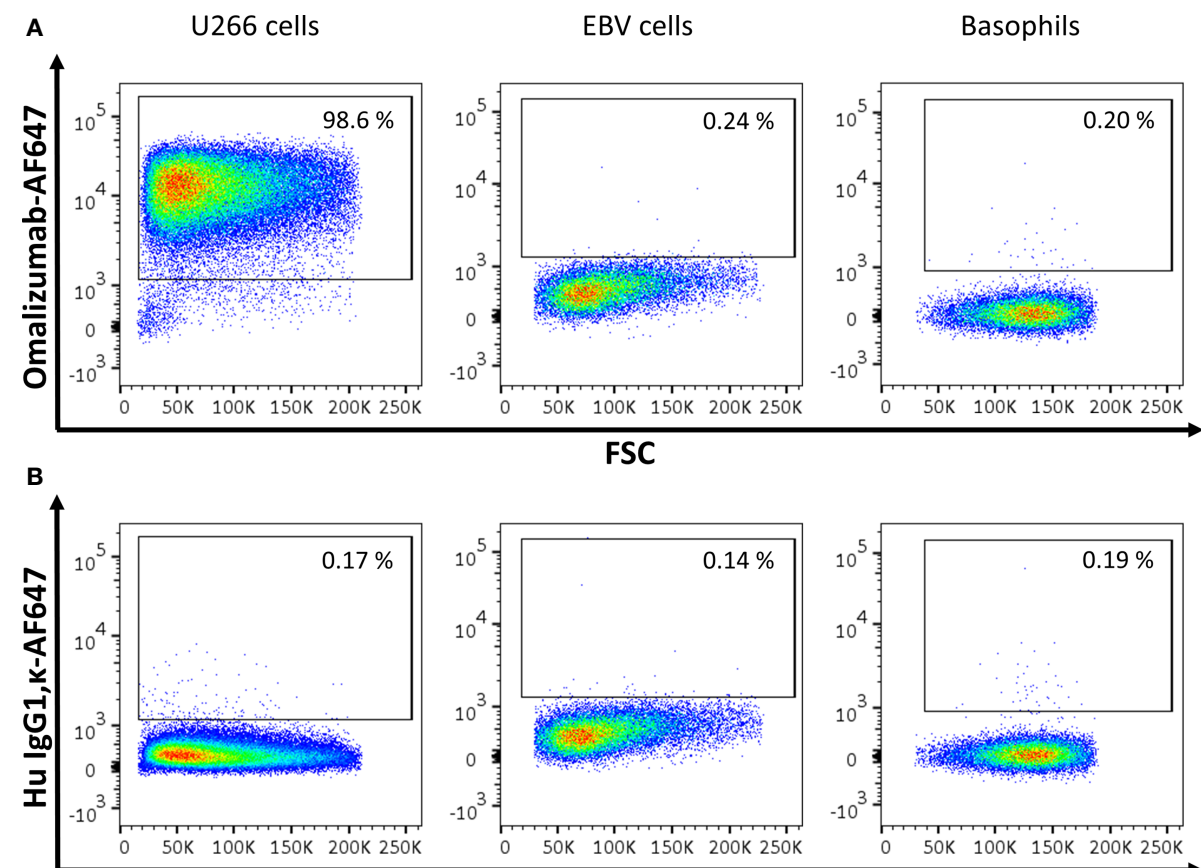

FSC
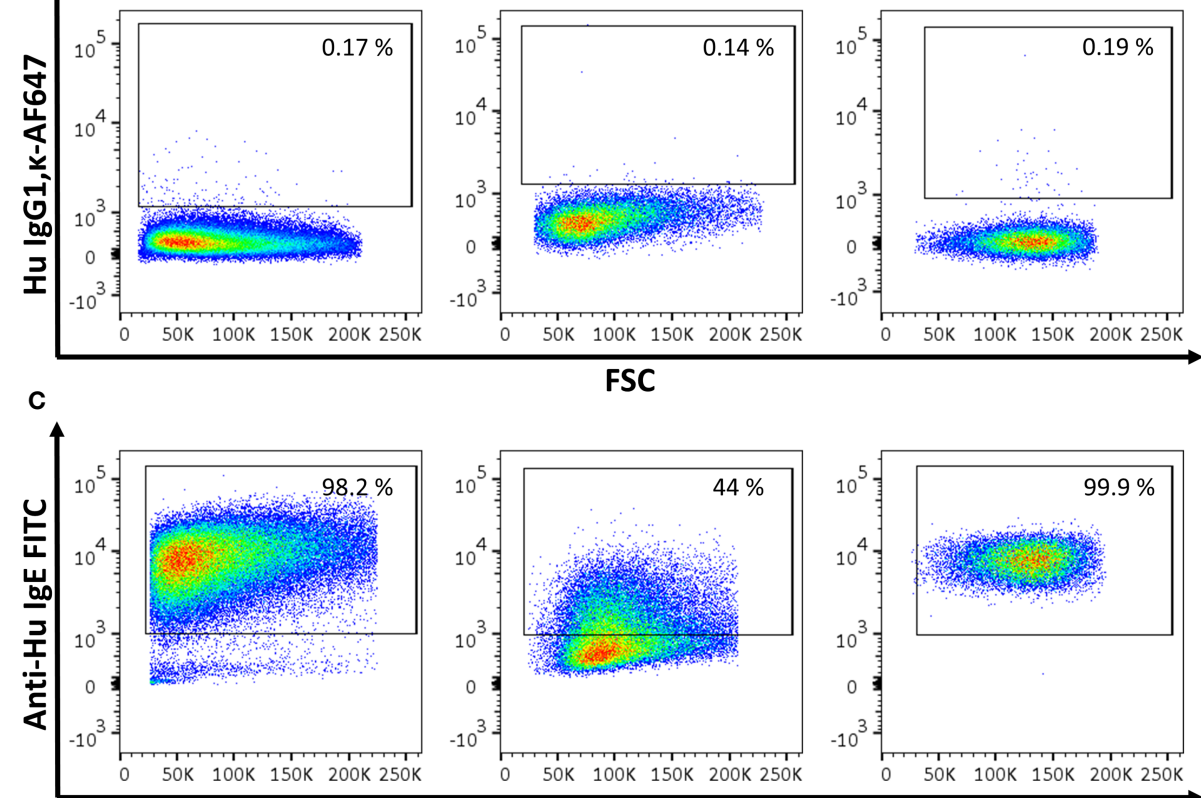

FSC
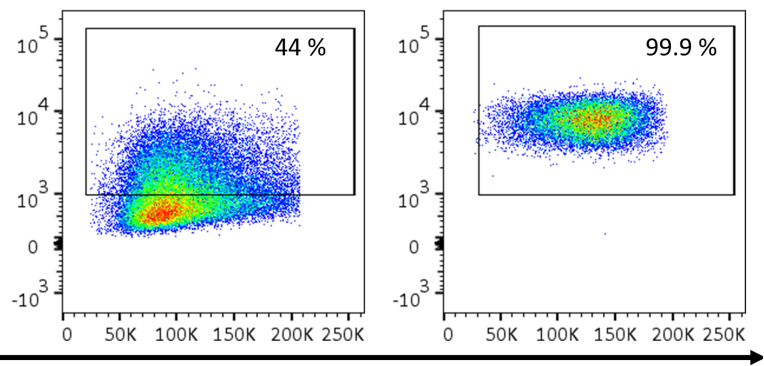

FSC

FIGURE 1 | Assessment of lgE-producing cells or cells bearing receptor-bound lgE by omalizumab or polyclonal anti-human lgE using flow cytometry. (A-C) Representative flow cytometric analysis of (left panels) U266, an IgE-producing cell line (U266 cells), (middle panels) an Epstein Barr virus-transformed human cell line bearing lgE bound to the low affinity receptor for lgE, CD23 (EBV cells), and (right panels) basophils enriched from human blood and bearing lgE bound to the high affinity receptor for lgE, FceRI. Plots depict forward scatter ( $\mathrm{x}$-axis) against (y-axis): (A) Alexa Fluor (AF) 647 labelled anti-human lgE antibody omalizumab, (B) the respective isotype control (human lgG1, $\mathrm{k}$ ) labelled with AF647 and (C) polyclonal anti-human IgE FITC. Cells were previously selected for alive cells by negative staining for efluor 780 viability dye and gates were set using isotype controls for omalizumab-AF647 or unstained cells for anti-human IgE FITC respectively. Experiments were performed in duplicates and representative plots of three independent experiments are shown.

proving its suitability for detection of rare $\operatorname{IgE}^{+} \mathrm{B}$ cells in human samples. As a proof of concept, we developed a sequential gating strategy allowing for the unambiguous identification of allergenspecific $\operatorname{IgE}^{+} \mathrm{MBCs}$ and $\mathrm{PBs} / \mathrm{PCs}$ in allergic patients.

Detection of rare antigen specific cells is challenging. In this context, one important step consists of the optimization of the signal to noise ratio (35). One option is to reduce background noise by enriching for $B$ cell subsets using e.g. magnetic separation or to exclude certain immune subsets in flow cytometric analysis using surface markers. With regards to $\mathrm{IgE}^{+} \mathrm{PCs}$, this strategy has successfully been applied in the past using microbeads containing antibodies against the plasma cell marker CD138 (36). However, it needs to be borne in mind with regards to $\operatorname{IgE}^{+} \mathrm{B}$ cells which are very poorly characterized in terms of surface markers that this always implies the danger of accidentally deleting or missing cells of interest as CD138 is not expressed by all human plasma cells $(37,38)$. Thus, we chose an alternative approach which was to maximize the signal of the rare cells. To achieve this, we used an approach of double staining allergen-specific $\operatorname{IgE}^{+} \mathrm{B}$ cells using both the allergen labelled with PE and omalizumab labelled with AF647 to clearly identify our population of interest. These two dyes have been carefully selected as they are currently among the brightest available fluorescent dyes, whereby especially AF647 has a very good profile in terms of photostability and signal to noise ratio as compared to other dyes in this channel such as 

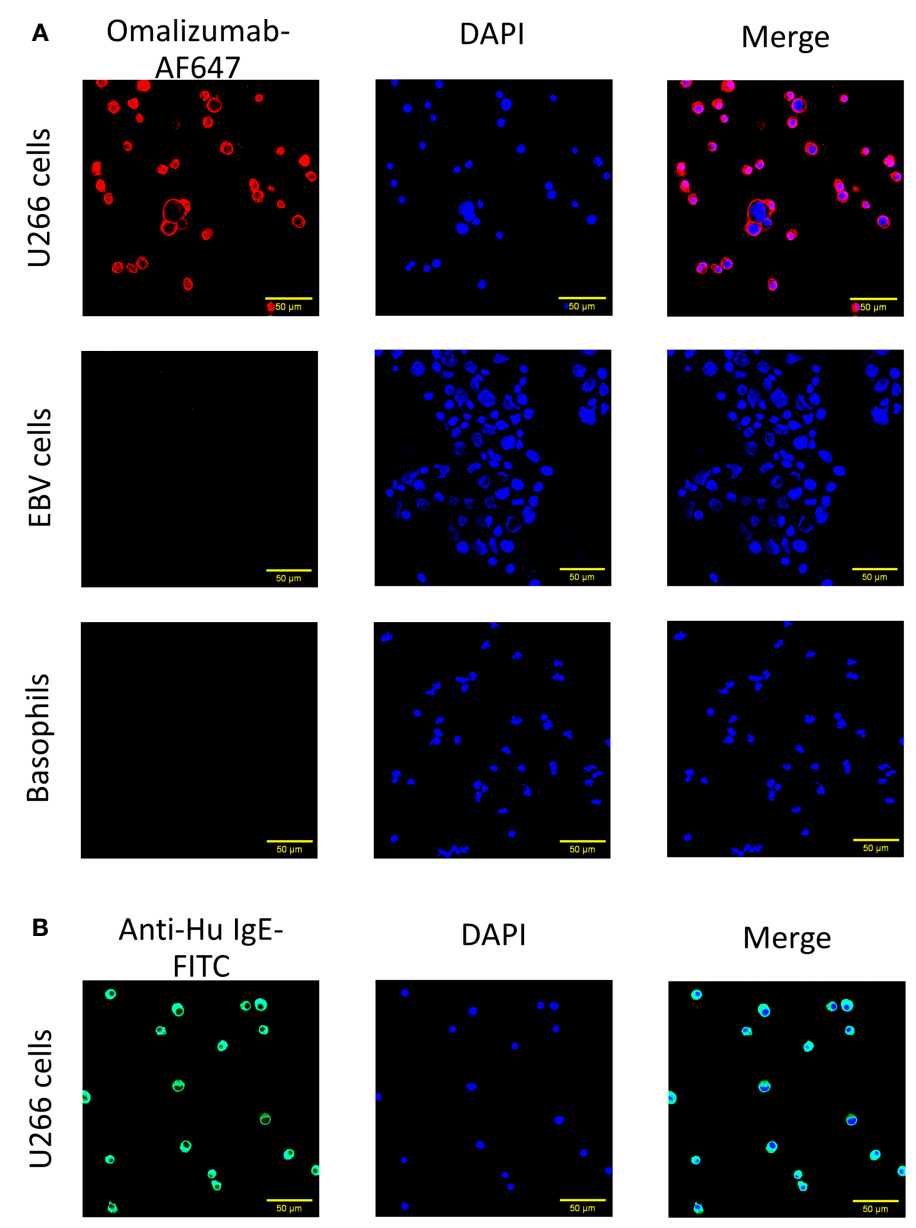

DAPI

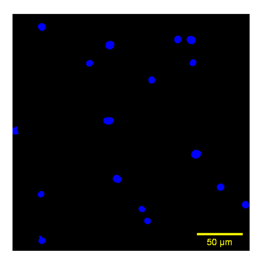

Merge
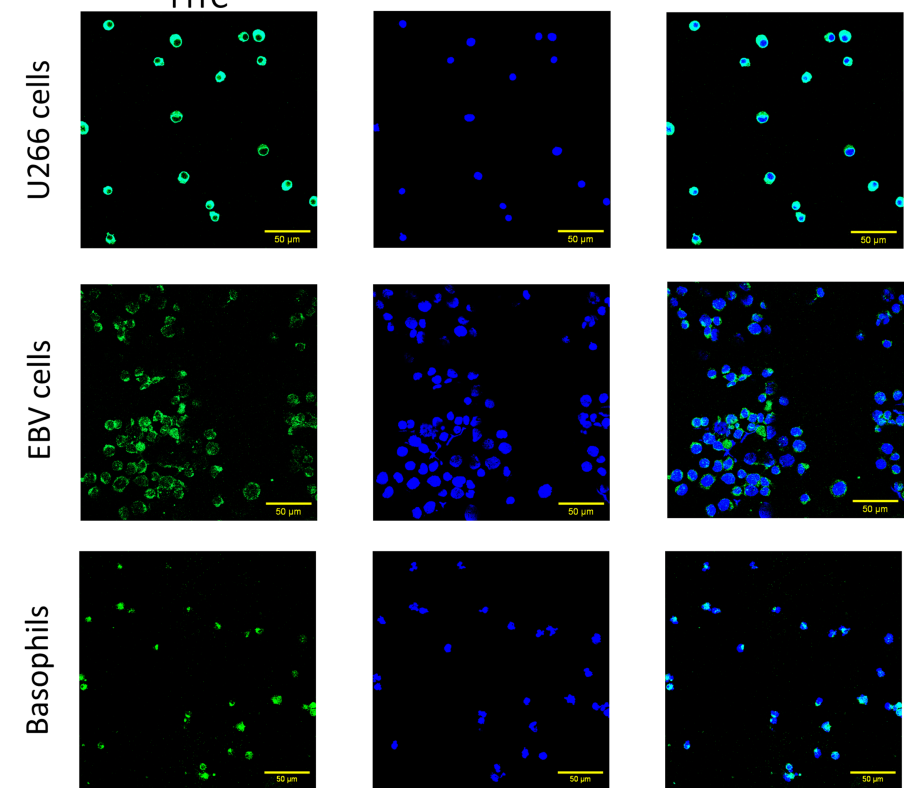

FIGURE 2 | Confocal imaging of IgE-producing cells or cells bearing receptor-bound lgE by omalizumab or polyclonal anti-human IgE. (A, B) Representative confocal images of (upper panels) U266, an IgE-producing cell line (U266 cells), (middle panels) an Epstein Barr virus-transformed human cell line bearing lgE bound to the low affinity receptor for lgE, CD23 (EBV cells) and (lower panels) basophils enriched from human blood and bearing lgE bound to the high affinity receptor for IgE, FceRl. Cells were stained with (A) Alexa Fluor (AF) 647 labelled anti-human lgE antibody omalizumab (red) or (B) polyclonal anti-human lgE FITC (green) to reveal IgE. Nuclei were counterstained with DAPI (blue) and samples analyzed by confocal microscopy. Data shown are representative of three independent experiments (scale bar is $50 \mu \mathrm{m})$.

APC $(39,40)$. Thus, we are able to maximize the signal and detect a clear Bet $\mathrm{v} 1 \mathrm{IgE}$ double-positive population in allergic but in not non-allergic subjects without using amplification steps such as allergen biotin tetramers which may introduce further background noise due to detection with fluorescent streptavidin (41).

In our experiments in cell lines as well as in patient-derived PBMCs, omalizumab exclusively and sensitively detected $\operatorname{IgE}^{+}$ 

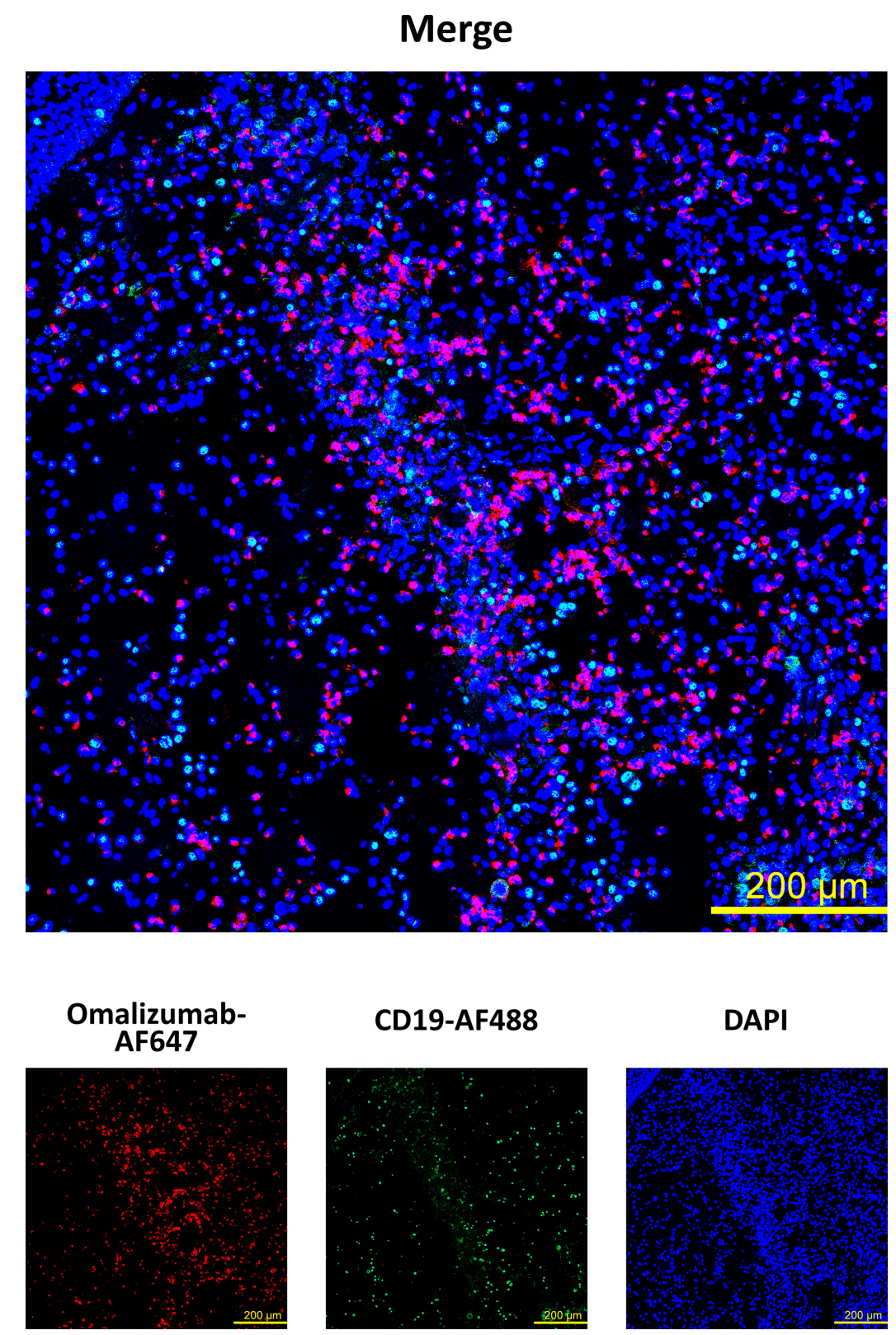

FIGURE 3 | Detection of IgE-producing cells in a nasal biopsy by omalizumab using confocal microscopy. IgE producing cells ( $n=100,000$, U266) were spiked onto cryosections from a nasal polyp using cytospin followed by staining with Alexa Fluor (AF) 647 labelled omalizumab (red) and anti-human CD19 (green). Nuclei were counterstained with DAPI (blue) and samples analyzed by confocal microscopy. Data shown are representative of three independent experiments (scale bar is 200 $\mu \mathrm{m}$ ).

MBCs, confirming our previous preliminary results (20). Due to its binding region in $\mathrm{C} \epsilon 3$ which is situated at the interface between the CD23 and FceRI binding site on IgE, this antibody was very well suited for our purposes. Additionally, we chose omalizumab as it is widely used and commercially available, however there are other conceivable alternative antibodies available potentially fulfilling these requirements. In this respect, Ligelizumab is also directed towards the C€3 region of $\operatorname{IgE}$ and binds with 50 times higher affinity to $\operatorname{IgE}$ in vitro (42). However, one caveat regarding this antibody is that omalizumab and Ligelizumab have distinct binding sites and thus inhibition profiles: While Ligelizumab is superior to omalizumab in inhibiting IgE FceRI interaction, its ability to block binding of $\operatorname{IgE}$ to $\mathrm{CD} 23$ is reduced $(43,44)$. Moreover, Ligelizumab has even been shown to be able to bind to CD23-bound IgE in confocal stainings (44). Thus, its ability to distinguish between IgE B cell antigen receptor- and CD23-bound IgE is reduced. Another alternative approach is the usage of antibodies directed specifically to regions only expressed in the membrane but not secreted form of IgE such as the transmembrane or extracellular 
A

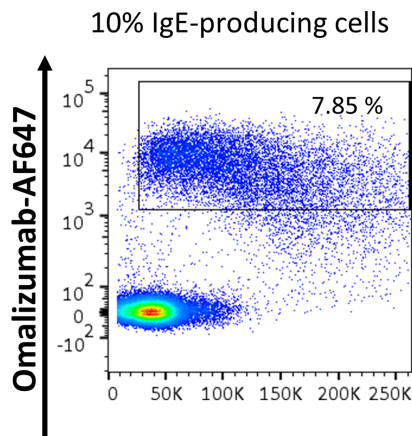

$1 \%$ IgE-producing cells

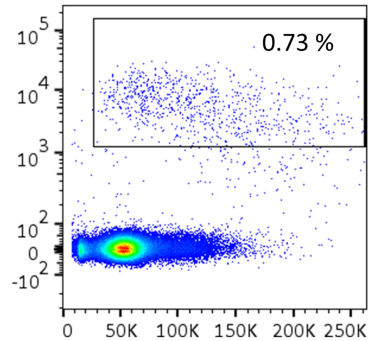

FSC
$0.1 \%$ IgE-producing cells

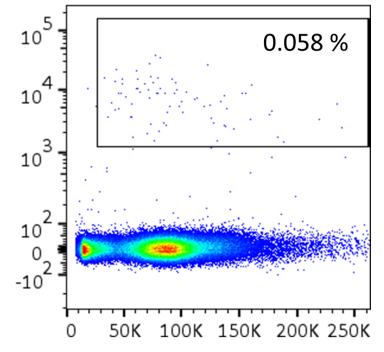

B

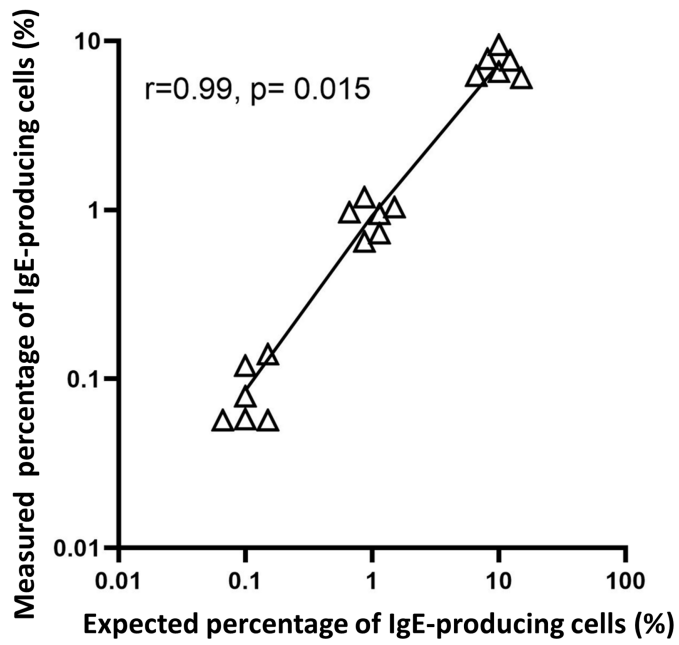

FIGURE 4 | Omalizumab specifically detects IgE-producing cells with a high sensitivity. (A) 1 million peripheral blood mononuclear cells from a healthy donor were spiked with (left panel) 10\% ( $n=100,000)$, (middle panel) 1\% ( $n=10,000)$ or (right panel) $0.1 \%$ ( $n=1000)$ lgE-producing cells (U266) followed by detection with Alexa Fluor (AF) 647-labelled omalizumab using flow cytometry. Gates were set using isotype control for omalizumab-AF647. (B) Scatter plot of expected (x-axis, \%) versus measured (y-axis, \%) percentage of IgE-producing cells spiked into PBMCs. Black triangles represent individual replicates from experiments, line represents the linear regression slope. Pearson's correlation coefficient with corresponding significance level is indicated in the figure. Data shown are representative of three independent experiments performed in duplicates.

membrane-proximal domains (45). In this respect the monoclonal antibodies $4 \mathrm{~B} 12$ binding to the proximal domain and the antibody 47HA directed towards the transmembrane M1 region have been shown to stain successfully free $\operatorname{IgE}(46,47)$ but are so far not commercially available.

Our consecutive gating strategy was based on previously published approaches distinguishing between memory B cells and plasma cells/blasts based on the surface markers CD38 in conjunction with negative staining for $\operatorname{IgM}$ and $\operatorname{IgD}$. In contrast to previous strategies, we did not further select for IgA and IgG negative cells for two reasons: Firstly, omalizumab is the first antibody used in flow cytometry that is able to directly identify B cells bearing membrane-bound IgE without need for additional selection steps. Secondly, B cells bear the Fc $\gamma$ receptors family member FcyRIIB and thus gating for IgG negative cells may also exclude $\operatorname{IgE}^{+} \mathrm{B}$ cells with $\mathrm{Fc} \gamma$ receptor bound IgG as commercial available anti-human IgG antibodies are not exclusively directed to free IgG present in the BCR (22-24). Alternatively, to using negative staining for IgM and IgD to select class switched B cells, CD27 in conjunction with CD19 and CD38 has been used as a marker to discriminate between naïve, memory cells and cells of the plasma cell lineage (8). However, it has been shown that CD27 is not expressed by all memory B cells but is rather an additional marker to discriminate memory B cell subsets (4850). In this line using a stepwise exclusion approach by gating on $\mathrm{CD}_{19}{ }^{+} \mathrm{CD} 38^{\mathrm{dim}}$ cells followed by exclusion of $\mathrm{IgM}^{+} \mathrm{IgD}^{+} \mathrm{IgG}^{+} \mathrm{IgA}^{+}$ cells it has been demonstrated that $\operatorname{IgE}^{+}$memory $\mathrm{B}$ cells expressing CD27 are most likely derived from a germinal center $\mathrm{T}$ cell-dependent pathway whereas $\operatorname{IgE}^{+}$memory B cells lacking expression of CD27 most likely have a $\mathrm{T}$ cell- 


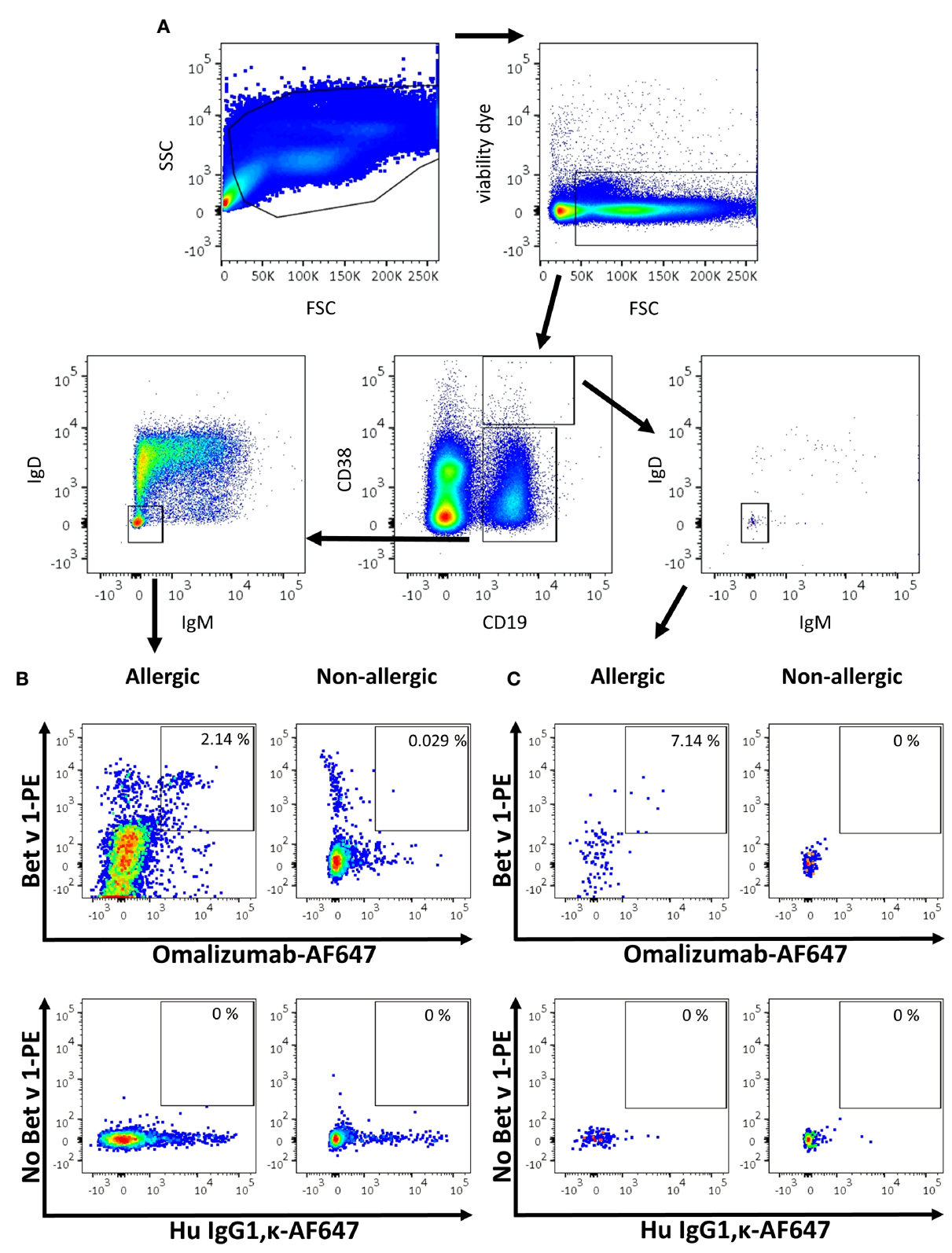

FIGURE 5 | Gating strategy for the detection of IgE MBCs and PBs/PCs using omalizumab in allergic and non-allergic patients. (A) Overview of the sequential gating strategy for the detection of IgE positive B cells in an allergic subject. (B, C) Comparison of the percentage of IgE positive Bet v 1 positive (B) memory B cells or (C) plasma blasts/plasma cells in (left panels) an allergic subject previously exposed to birch pollen or (right panels) a non-allergic subject. Plots depict (upper panels) Alexa Fluor 647-labelled omalizumab ( $x$-axis) against PE-labelled Bet $v 1$ (y-axis), and (lower panels) the respective isotype control (human lgG1, $\kappa, x$-axis) labelled with AF647 in the absence of Bet $v 1$ (y-axis). Plots are representative for 5 allergic and 3 non-allergic subjects.

independent origin (7). Thus, as a substantial portion of $\operatorname{IgE}^{+} \mathrm{B}$ cells do not express CD27, we did not use this marker for our gating approach.

Using a double staining with omalizumab and labelled birch pollen allergen, we identified an average of $3.228 \% \operatorname{IgE}^{+}$Bet v $1^{+}$ cells of total MBCs in 5 allergen-provoked birch pollen allergic patients, and $2.030 \% \mathrm{IgE}^{+}$Bet $\mathrm{v} 1^{+}$cells of total PBs/PCs. When compared to the total number of $\mathrm{B}$ cells, these amounts correspond to $0.734 \% \mathrm{IgE}^{+}$Bet $\mathrm{v} 1^{+} \mathrm{MBC}$ s of total $\mathrm{CD} 19^{+} \mathrm{B}$ cells (range: $0.4-1.1 \%$ ) and $0.018 \%$ IgE $^{+}$Bet v $1^{+} \mathrm{PBs} / \mathrm{PCs}$ of total CD19+ B cells (range: 0.00-0.06\%) (Supplementary Table S3). Bearing in mind that the patients in our study were exposed to allergen shortly before the blood draw and that we did not observe any allergen-specific $\mathrm{IgE}^{+} \mathrm{B}$ cells in non-allergic patients or allergic patients prior to allergen challenge (data not shown), our data are in line with a recent study from R. Jimenez-Saiz suggesting that percentage of $\mathrm{IgE}^{+}$memory cells in the absence of allergen challenge is magnitudes lower (6) than the previously 
reported $0.2 \%$ to $0.3 \%$ of total $\mathrm{CD}^{+} 9^{+} \mathrm{B}$ cells (7-9). Our data indicates that allergen-specific $\operatorname{IgE}^{+}$memory $\mathrm{B}$ cells can be detected in blood but most likely only after allergen exposure, using a stringent gating approach. Where these cells may reside outside the season remains elusive (4). As the main aim of this study was the establishment of a consecutive gating strategy to reliably detect these cells, we applied our approach only in bloodderived cells. This is a limitation of this study as the majority of IgE-producing cells will reside elsewhere (4). However, based on our spiking experiments in nasal polyp tissue, we are confident that in future studies this strategy can also be used for the identification of IgE B cell antigen receptor-bearing and IgEproducing cells in various tissues.

In summary, we identified the anti-human IgE antibody omalizumab as a valuable tool for clear identification of $\operatorname{IgE}$ producing and IgE BCR-bearing B cells and established a step wise gating strategy allowing for the unambiguous identification of these cells in human blood derived PBMCs. Our strategy provides a useful tool for the investigation of human IgE memory cells.

\section{DATA AVAILABILITY STATEMENT}

The raw data supporting the conclusions of this article will be made available by the authors, without undue reservation.

\section{ETHICS STATEMENT}

The studies involving human participants were reviewed and approved by Ethical Committee of the Medical University of

\section{REFERENCES}

1. Valenta R, Karaulov A, Niederberger V, Gattinger P, van Hage M, Flicker S, et al. Molecular Aspects of Allergens and Allergy. Adv Immunol (2018) 138:195-256. doi: 10.1016/bs.ai.2018.03.002

2. Lupinek C, Derfler K, Lee S, Prikoszovich T, Movadat O, Wollmann E, et al. Extracorporeal IgE Immunoadsorption in Allergic Asthma: Safety and Efficacy. EBioMedicine (2017) 17:119-33. doi: 10.1016/j.ebiom.2017.02.007

3. Wu LC, Zarrin AA. The Production and Regulation of IgE by the Immune System. Nat Rev Immunol (2014) 14(4):247-59. doi: 10.1038/nri3632

4. Eckl-Dorna J, Niederberger V. What Is the Source of Serum Allergen-Specific IgE? Curr Allergy Asthma Rep (2013) 13(3):281-7. doi: 10.1007/s11882-0130348-X

5. Asrat S, Kaur N, Liu X, Ben LH, Kajimura D, Murphy AJ, et al. Chronic Allergen Exposure Drives Accumulation of Long-Lived IgE Plasma Cells in the Bone Marrow, Giving Rise to Serological Memory. Sci Immunol (2020) 5 (43):eaav8402. doi: 10.1126/sciimmunol.aav8402

6. Jimenez-Saiz R, Ellenbogen Y, Bruton K, Spill P, Sommer DD, Lima H, et al. Human BCR Analysis of Single-Sorted, Putative IgE(+) Memory B Cells in Food Allergy. J Allergy Clin Immunol (2019) 144(1):336-339. doi: 10.1101/ 510743

7. Berkowska MA, Heeringa JJ, Hajdarbegovic E, van der Burg M, Thio HB, van Hagen PM, et al. Human IgE(+) B Cells Are Derived From T Cell-Dependent and T Cell-Independent Pathways. J Allergy Clin Immunol (2014) 134(3):68897 e6. doi: 10.1016/j.jaci.2014.03.036

8. Oliveria JP, Salter BM, MacLean J, Kotwal S, Smith A, Harris JM, et al. Increased $\operatorname{IgE}(+)$ B Cells in Sputum, But Not Blood, Bone Marrow, or Tonsils, After Inhaled Allergen Challenge in Subjects With Asthma. Am J Respir Crit Care Med (2017) 196(1):107-9. doi: 10.1164/rccm.201611-2274LE
Vienna. The patients/participants provided their written informed consent to participate in this study.

\section{AUTHOR CONTRIBUTIONS}

MZ, JE-D, and RV designed the study and wrote the manuscript. $\mathrm{HB}, \mathrm{SF}, \mathrm{VN}-\mathrm{L}, \mathrm{MB}, \mathrm{NC}$, VS, AT, and SV-M provided reagents and participated in the design and/or conduct of experiments. $\mathrm{MZ}$ performed the experiments and wrote the first draft of the manuscript. All co-authors critically revised the manuscript. All authors contributed to the article and approved the submitted version.

\section{FUNDING}

This work was supported by the Country of Lower Austria's funded Danube Allergy research cluster, by grants DK W 1248B30 and SFB F4613 from the Austrian Science Fund (FWF), by a Megagrant of the Government of the Russian Federation, grant No 14.W03.31.0024 and in part by the Russian Science Foundation, grant No 21-15-00286.

\section{SUPPLEMENTARY MATERIAL}

The Supplementary Material for this article can be found online at: https://www.frontiersin.org/articles/10.3389/fimmu.2021.803236/ full\#supplementary-material

9. Heeringa JJ, Rijvers L, Arends NJ, Driessen GJ, Pasmans SG, van Dongen JJM, et al. IgE-Expressing Memory B Cells and Plasmablasts Are Increased in Blood of Children With Asthma, Food Allergy, and Atopic Dermatitis. Allergy (2018) 73(6):1331-6. doi: 10.1111/all.13421

10. Eckl-Dorna J, Pree I, Reisinger J, Marth K, Chen KW, Vrtala S, et al. The Majority of Allergen-Specific IgE in the Blood of Allergic Patients Does Not Originate From Blood-Derived B Cells or Plasma Cells. Clin Exp Allergy (2012) 42(9):1347-55. doi: 10.1111/j.1365-2222.2012.04030.x

11. Karnowski A, Achatz-Straussberger G, Klockenbusch C, Achatz G, Lamers MC. Inefficient Processing of mRNA for the Membrane Form of IgE Is a Genetic Mechanism to Limit Recruitment of IgE-Secreting Cells. Eur J Immunol (2006) 36(7):1917-25. doi: 10.1002/eji.200535495

12. Engels N, Wienands J. Memory Control by the B Cell Antigen Receptor. Immunol Rev (2018) 283(1):150-60. doi: 10.1111/imr.12651

13. Schmitt ME, Lutz J, Haase P, Bösl MR, Wienands J, Engels N, et al. The B-Cell Antigen Receptor of IgE-Switched Plasma Cells Regulates Memory IgE Responses. J Allergy Clin Immunol (2020) 146(3):642-51. doi: 10.1016/ j.jaci.2020.02.015

14. Frigeri LG, Liu FT. Surface Expression of Functional IgE Binding Protein, an Endogenous Lectin, on Mast Cells and Macrophages. J Immunol (1992) 148 (3):861-7.

15. Selb R, Eckl-Dorna J, Neunkirchner A, Schmetterer K, Marth K, Gamper J, et al. CD23 Surface Density on B Cells Is Associated With IgE Levels and Determines IgE-Facilitated Allergen Uptake, as Well as Activation of Allergen-Specific T Cells. J Allergy Clin Immunol (2017) 139(1):290-9.e4. doi: 10.1016/j.jaci.2016.03.042

16. Shamji MH, Valenta R, Jardetzky T, Verhasselt V, Durham SR, Wurtzen PA, et al. The Role of Allergen-Specific IgE, IgG and IgA in Allergic Disease. Allergy (2021). doi: 10.1111/all.14908 
17. Katona IM, Urban JF Jr, Scher I, Kanellopoulos-Langevin C, Finkelman FD. Induction of an IgE Response in Mice by Nippostrongylus Brasiliensis: Characterization of Lymphoid Cells With Intracytoplasmic or Surface IgE. J Immunol (1983) 130(1):350-6. doi: 10.1016/S0091-6749(62)80475-8

18. Erazo A, Kutchukhidze N, Leung M, Christ AP, Urban JF Jr, Curotto de Lafaille MA, et al. Unique Maturation Program of the IgE Response In Vivo. Immunity (2007) 26(2):191-203. doi: 10.1016/j.immuni.2006.12.006

19. Galeotti C, Karnam A, Das M, Kaveri SV, Bayry J. Acid Stripping of Surface IgE Antibodies Bound to FcepsilonRI Is Unsuitable for the Functional Assays That Require Long-Term Culture of Basophils and Entire Removal of Surface IgE. Int J Mol Sci (2020) 21(2):510. doi: 10.3390/ ijms 21020510

20. Eckl-Dorna J, Villazala-Merino S, Campion NJ, Byazrova M, Filatov A, Kudlay D, et al. Tracing IgE-Producing Cells in Allergic Patients. Cells (2019) 8(9):994. doi: 10.3390/cells8090994

21. Croote D, Darmanis S, Nadeau KC, Quake SR. High-Affinity Allergen-Specific Human Antibodies Cloned From Single IgE B Cell Transcriptomes. Sci (New York NY (2018) 362(6420):1306-9. doi: 10.1126/science.aau2599

22. Rosales C. Fcgamma Receptor Heterogeneity in Leukocyte Functional Responses. Front Immunol (2017) 8:280. doi: 10.3389/fimmu.2017.00280

23. Veri MC, Gorlatov S, Li H, Burke S, Johnson S, Stavenhagen J, et al. Monoclonal Antibodies Capable of Discriminating the Human Inhibitory Fcgamma-Receptor IIB (CD32B) From the Activating Fcgamma-Receptor IIA (CD32A): Biochemical, Biological and Functional Characterization. Immunology (2007) 121(3):392-404. doi: 10.1111/j.1365-2567.2007.02588.x

24. Chu SY, Horton HM, Pong E, Leung IW, Chen H, Nguyen DH, et al. Reduction of Total IgE by Targeted Coengagement of IgE B-Cell Receptor and FcgammaRIIb With Fc-Engineered Antibody. J Allergy Clin Immunol (2012) 129(4):1102-15. doi: 10.1016/j.jaci.2011.11.029

25. Milgrom H, Fick RB Jr, Su JQ, Reimann JD, Bush RK, Watrous ML, et al. Treatment of Allergic Asthma With Monoclonal Anti-IgE Antibody. rhuMAb-E25 Study Group. New Engl J Med (1999) 341(26):1966-73. doi: 10.1056/NEJM199912233412603

26. Guzelbey O, Ardelean E, Magerl M, Zuberbier T, Maurer M, Metz M. Successful Treatment of Solar Urticaria With Anti-Immunoglobulin E Therapy. Allergy (2008) 63(11):1563-5. doi: 10.1111/j.1398-9995.2008. 01879.x

27. Busse W, Corren J, Lanier BQ, McAlary M, Fowler-Taylor A, Cioppa GD, et al. Omalizumab, Anti-IgE Recombinant Humanized Monoclonal Antibody, for the Treatment of Severe Allergic Asthma. J Allergy Clin Immunol (2001) 108(2):184-90. doi: 10.1067/mai.2001.117880

28. Selb R, Eckl-Dorna J, Twaroch TE, Lupinek C, Teufelberger A, Hofer G, et al. Critical and Direct Involvement of the CD23 Stalk Region in IgE Binding. J Allergy Clin Immunol (2017) 139(1):281-9.e5. doi: 10.1016/ j.jaci.2016.04.015

29. Laffer S, Lupinek C, Rauter I, Kneidinger M, Drescher A, Jordan JH, et al. A High-Affinity Monoclonal Anti-IgE Antibody for Depletion of IgE and IgEBearing Cells. Allergy (2008) 63(6):695-702. doi: 10.1111/j.1398-9995.2008. 01664.x

30. Eckl-Dorna J, Ellinger A, Blatt K, Ghanim V, Steiner I, Pavelka M, et al. Basophils Are Not the Key Antigen-Presenting Cells in Allergic Patients. Allergy (2012) 67(5):601-8. doi: 10.1111/j.1398-9995.2012.02792.x

31. Laffer S, Hogbom E, Roux KH, Sperr WR, Valent P, Bankl HC, et al. A Molecular Model of Type I Allergy: Identification and Characterization of a Nonanaphylactic Anti-Human IgE Antibody Fragment that Blocks the IgEFceRI Interaction and Reacts with Receptor-Bound IgE. J Allergy Clin Immunol (2001) 108(3):409-16. doi: 10.1067/mai.2001.117593

32. Johansson SG, Bennich H. Immunological Studies of an Atypical (Myeloma) Immunoglobulin. Immunology (1967) 13(4):381-94.

33. Nilsson K, Bennich H, Johansson SG, Ponten J. Established Immunoglobulin Producing Myeloma (IgE) and Lymphoblastoid (IgG) Cell Lines From an IgE Myeloma Patient. Clin Exp Immunol (1970) 7(4):477-89.

34. Villazala-Merino S, Rodriguez-Dominguez A, Stanek V, Campion NJ, Gattinger P, Hofer G, et al. Allergen-Specific IgE Levels and the Ability of IgE-Allergen Complexes to Cross-Link Determine the Extent of CD23Mediated T-Cell Activation. J Allergy Clin Immunol (2020) 145(3):95867.e5. doi: 10.1016/j.jaci.2019.11.019
35. Hedley BD, Keeney M. Technical Issues: Flow Cytometry and Rare Event Analysis. Int J Lab Hematol (2013) 35(3):344-50. doi: 10.1111/ ijlh. 12068

36. Horst A, Hunzelmann N, Arce S, Herber M, Manz RA, Radbruch A, et al. Detection and Characterization of Plasma Cells in Peripheral Blood: Correlation of IgE+ Plasma Cell Frequency With IgE Serum Titre. Clin Exp Immunol (2002) 130(3):370-8. doi: 10.1046/j.1365-2249.2002. 02025.x

37. Caraux A, Klein B, Paiva B, Bret C, Schmitz A, Fuhler GM, et al. Circulating Human B and Plasma Cells. Age-Associated Changes in Counts and Detailed Characterization of Circulating Normal CD138- and CD138+ Plasma Cells. Haematologica (2010) 95(6):1016-20. doi: 10.3324/haematol. 2009.018689

38. Medina F, Segundo C, Campos-Caro A, Gonzalez-Garcia I, Brieva JA. The Heterogeneity Shown by Human Plasma Cells From Tonsil, Blood, and Bone Marrow Reveals Graded Stages of Increasing Maturity, But Local Profiles of Adhesion Molecule Expression. Blood (2002) 99(6):2154-61. doi: 10.1182/ blood.V99.6.2154

39. Rai S, Bhardwaj U, Misra A, Singh S, Gupta R. Comparison Between Photostability of Alexa Fluor 448 and Alexa Fluor 647 With Conventional Dyes FITC and APC by Flow Cytometry. Int J Lab Hematol (2018) 40(3):e52-4. doi: $10.1111 /$ ijlh.12809

40. Chattopadhyay PK, Gaylord B, Palmer A, Jiang N, Raven MA, Lewis G, et al. Brilliant Violet Fluorophores: A New Class of Ultrabright Fluorescent Compounds for Immunofluorescence Experiments. Cytometry A (2012) 81 (6):456-66. doi: 10.1002/cyto.a.22043

41. Franz B, May KF Jr, Dranoff G, Wucherpfennig K. Ex Vivo Characterization and Isolation of Rare Memory B Cells With Antigen Tetramers. Blood (2011) 118(2):348-57. doi: 10.1182/blood-2011-03-341917

42. Arm JP, Bottoli I, Skerjanec A, Floch D, Groenewegen A, Maahs S, et al. Pharmacokinetics, Pharmacodynamics and Safety of QGE031 (Ligelizumab), a Novel High-Affinity Anti-IgE Antibody, in Atopic Subjects. Clin Exp Allergy (2014) 44(11):1371-85. doi: 10.1111/cea.12400

43. Adelroth E, Rak S, Haahtela T, Aasand G, Rosenhall L, Zetterstrom O, et al. Recombinant Humanized mAb-E25, an Anti-IgE mAb, in Birch PollenInduced Seasonal Allergic Rhinitis. J Allergy Clin Immunol (2000) 106 (2):253-9. doi: 10.1067/mai.2000.108310

44. Gasser P, Tarchevskaya SS, Guntern P, Brigger D, Ruppli R, Zbaren N, et al. The Mechanistic and Functional Profile of the Therapeutic Anti-IgE Antibody Ligelizumab Differs From Omalizumab. Nat Commun (2020) 11(1):165. doi: 10.1038/s41467-019-13815-w

45. Zhang K, Saxon A, Max EE. Two Unusual Forms of Human Immunoglobulin E Encoded by Alternative RNA Splicing of Epsilon Heavy Chain Membrane Exons. J Exp Med (1992) 176(1):233-43. doi: 10.1084/jem. 176.1.233

46. Ramadani F, Bowen H, Upton N, Hobson PS, Chan YC, Chen JB, et al. Ontogeny of Human IgE-Expressing B Cells and Plasma Cells. Allergy (2017) 72(1):66-76. doi: 10.1111/all.12911

47. Brightbill HD, Jeet S, Lin Z, Yan D, Zhou M, Tan M, et al. Antibodies Specific for a Segment of Human Membrane IgE Deplete IgE-Producing B Cells in Humanized Mice. J Clin Invest (2010) 120(6):2218-29. doi: 10.1172/ JCI40141

48. Wu YC, Kipling D, Dunn-Walters DK. The Relationship Between CD27 Negative and Positive B Cell Populations in Human Peripheral Blood. Front Immunol (2011) 2:81. doi: 10.3389/fimmu.2011.00081

49. Sanz I, Wei C, Lee FE, Anolik J. Phenotypic and Functional Heterogeneity of Human Memory B Cells. Semin Immunol (2008) 20(1):67-82. doi: 10.1016/ j.smim.2007.12.006

50. Berkowska MA, Driessen GJ, Bikos V, Grosserichter-Wagener C, Stamatopoulos K, Cerutti A, et al. Human Memory B Cells Originate From Three Distinct Germinal Center-Dependent and -Independent Maturation Pathways. Blood (2011) 118(8):2150-8. doi: 10.1182/blood2011-04-345579

Conflict of Interest: RV has received research grants from Worg Pharmaceuticals, Hangzhou, China, HVD Biotech, Vienna, Austria and Viravaxx, Vienna, Austria. He serves as a consultant for Viravaxx and Worg. 
The remaining authors declare that the research was conducted in the absence of any commercial or financial relationships that could be construed as a potential conflict of interest.

Publisher's Note: All claims expressed in this article are solely those of the authors and do not necessarily represent those of their affiliated organizations, or those of the publisher, the editors and the reviewers. Any product that may be evaluated in this article, or claim that may be made by its manufacturer, is not guaranteed or endorsed by the publisher.

Citation: Zghaebi M, Byazrova M, Flicker S, Villazala-Merino S, Campion NJ, Stanek V, Tu A, Breiteneder H, Filatov A, Khaitov M, Niederberger-Leppin V,
Eckl-Dorna J and Valenta R (2021) Tracing Human IgE B Cell Antigen ReceptorBearing Cells With a Monoclonal Anti-Human IgE Antibody That Specifically Recognizes Non-Receptor-Bound IgE.

Front. Immunol. 12:803236. doi: 10.3389/fimmu.2021.803236

Copyright (c) 2021 Zghaebi, Byazrova, Flicker, Villazala-Merino, Campion, Stanek, Tu, Breiteneder, Filatov, Khaitov, Niederberger-Leppin, Eckl-Dorna and Valenta. This is an open-access article distributed under the terms of the Creative Commons Attribution License (CC BY). The use, distribution or reproduction in other forums is permitted, provided the original author(s) and the copyright owner(s) are credited and that the original publication in this journal is cited, in accordance with accepted academic practice. No use, distribution or reproduction is permitted which does not comply with these terms. 